Viewpoints and Letters to the Editor are published in Hort- comments on matters of concern to horticulturists. These are Science to provide members of the American Society for Hor- not statements of official Society policy nor do they necessarticultural Science an opportunity to share their experiences and ily reflect the views of a majority of the Society's members.

\title{
Developmental Indices of Peach: An Anatomical Framework
}

\author{
James Gage and Gary Stutte \\ Department of Horticulture, University of Maryland, College Park MD 20742
}

\begin{abstract}
Many factors affect the growth and development of peach fruit. Unlike the more easily controlled environments of the laboratory and greenhouse, field researchers are limited in their ability to control the microclimate, soil, and cultural conditions that affect peach growth and development. As a result, variability within a peach population is often greater than variability among experimental treatments.
\end{abstract}

The date of full bloom in peach can vary substantially from year to year. In a 10-year study by Weinberger (1948), full bloom of Georgia-grown 'Elberta' varied between 1 Mar. and 4 Apr. This, in part, resulted from growing seasons that ranged from 104 to 124 days. In our studies covering 5 years at Beltsville, Md. (1985-1989), full bloom was spread over 9 days, from 31 Mar. to $8 \mathrm{Apr}$.

Full bloom, the time of maximum blossom opening, is something of a misnomer. Populations of blossoms may open and become fertilized over several days; therefore, precise assessment of full bloom is difficult (Ragland, 1934). Fischer (1962) noted that the determination of full bloom is subject to personal bias that introduces an inherent variability into the chronological description of subsequent developmental events.

Growth of peach fruit is temperature dependent. Efforts to quantify the temperature requirements for fruit maturation have been made by several workers (Baker and Brooks, 1944; Brown, 1952; Fischer, 1962; Munoz et al., 1986). Batjer and Martin (1965) showed that nighttime low temperatures delay maturity throughout the growing season. Moderate nighttime temperatures accelerate fruit growth primarily during Stages I and II of development when ambient temperatures are low. This phenomenon could explain differences in length of season between growing regions, and even within different areas of the same orchard. Topp and Sherman (1989) used mean monthly temperatures to explain variability in ripening period at 13 locations in Australia. Regression analysis of mean fruit

Received for publication 19 Oct. 1989. Scientific article no. A-5032, contribution no. 8080 of the Maryland Agricultural Experiment Station, College Park. The cost of publishing this paper was defrayed in part by the payment of page charges. Under postal regulations, this paper therefore must be hereby marked advertisement solely to indicate this fact. growing season temperatures with fruit development period showed a 5-day delay in ripening period for each $1 \mathrm{C}$ reduction in temperature.

Because of the variability in early fruit growth, classification of distinct stages of growth and development is especially difficult in peach. However, the responses to different experimental treatments do seem dependent on developmental stage of the fruit. Lombard and Mitchell (1962) found that sensitivity of peach fruit abscission to naphthalene-acetic acid (NAA) decreased with time. They attributed this difference to embryo development and hormone content of the seed. Stutte and Gage (1990) found a differential response between gibberellic acid (GA) treatments of embryo aborted fruit at 30, 40, and 50 days after full bloom (DAFB). Fruit from the 30-day treatment developed a pit, underwent final swell, and ripened normally, whereas fruit treated at 40 and 50 DAFB abscised. We attributed these findings to a differential sensitivity to GA between early and late Stage I of development. These examples emphasize the value of a developmental index for determining anatomical events. However, the precision of the indices in predicting anatomical events is not known.

The object of this report is to describe the available indices for the growth and development of peach fruit, to develop a continuum of early fruit development that can function as a tool for experimental design and evaluation, and suggest a means of extrapolating developmental processes among different growing regions.

\section{Indices of peach fruit growth}

There are four major types of indices used to describe the growth and development of peach fruit: 1) chronological; 2) morphological; 3) environmental; and 4) physiological. The advantages and limitations of each are described below.

A chronological index can be based on the Julian date, the calendar date, the days after a specific morphological event (usually full bloom or anthesis), or the days after a specific treatment. The Julian date is useful as it can be matched a posteriori to other data (rainfall, temperature, etc.); it does not, however, describe the development of the target fruit. The calendar date has the advantage of being a universally recognized system that makes relative comparisons possible. It is more difficult to integrate into a model than a Julian date because the number of days in a month is not constant. Days after full bloom is a graduated index based on an important morphological event. The variability in bloom and the variability of environmental effects decrease its precision. Days after a specific treatment could minimize the importance of the anatomical stage on the success/failure of the treatment, focusing only on the results of the treatment.

Fruit morphological indices have also been used to classify the growth stages of fruit. The three-stage double sigmoidal curve (Connors, 1919) is commonly used to describe the development of peach fruit by diameter and weight. Stage I is characterized by cell division and rapid development of the endosperm, Stage II by endocarp sclerification (pit hardening), and Stage III by rapid expansion of mesocarp cells (final swell).

Changes in measured rates of growth have led researchers to hypothesize that competition during fruit development is responsible for the growth stages. Various hypotheses have been proposed to describe competition within an individual fruit, competition between reproductive and nonreproductive sinks, and endogenous control of these events. External measures of fruit diameter or volume are indicators of pericarp activity, and, because of variability of fruit, environmental factors, and differentiation of the tissues, do not define developmental events (Zucconi, 1987). One example is the hypothesis that the developing seed controls the onset of Stage II: The work of Crane (1963) with parthenocarpic fruit and Stutte and Gage (1990) with GA-treated, embryo-aborted fruit both show that normal fruit size and pit development are possible without the presence of a viable ovule.

An environmental index is an attractive framework for a developmental chronology since it provides an objective, readily measured parameter that has quantitative effects on fruit development. Fischer (1962) was one of first to use heat unit accumulation to explain site specific differences in growing season. More recently, Topp and Sherman (1989) determined the effect of average daily temperatures on the ripening period of several peach cultivars. Munoz et al. (1986) have determined cultivar-specific differences in the perception of heat units. DeJong and Goud- 
Table 1. Anatomical changes during Stage I of peach fruit development (dashed lines indicate time course). ${ }^{2}$

\begin{tabular}{ccccc}
\hline \hline 0 & & & Days after full bloom & \\
\hline & 10 & 20 & 30 & 40 \\
\hline & Initial phase of exponential growth-Stage 1 (2) & Growth lag (variable with cultivar)-Stage II & 60 \\
\hline
\end{tabular}

Growth rate of length of fruit

most rapid (1)

Cell division rapid (1)

Cell division in all directions (1)

Cell division most active in

basal portion of carpel (8)

Cells of inner flesh become

vacuolated (8)

Cells feature a thin layer of proto-

plasm (except hypodermal region) (8)

Mesocarp and exocarp

\section{Cell division slows . . ceases $(1,8,10)$ \\ Growth rate of cheek diameter most rapid}

Cell division longest in epidermal

and hypodermal layers $(8,10)$

Cell division continues longest at

basal end (8)

Cell expansion

Outer mesocarp cells

Epidermis become more ovoid (1)

Inner mesocarp cells elongate radially (1)

Intercellular spaces

are small $(1,10)$

Small chloroplasts are abundant

in outer mesocarp; larger

than those in the interior

and containing more starch (1)

Epidermis is heavily cutinized. Exhibits thick

layer of trichomes (1)

Vascular bundles

Bundles extend into flesh throughout

active cell division (8)
Duct formation

Large ducts extend the entire length

of the fruit; isolated phloem

parenchyma cells extend into the

duct cavity (8)
Parenchyma cell walls thicken (9)

Asymmetric development around the suture-the embryo sustaining half of the mesocarp grows larger and ripens earlier (10)

Hypodermal cells

At pit hardening, hypodermal layer is $6-10$ cells thick $(1,8)$

Hypodermal cells have thicker walls but are smaller than mesocarp cells $(1,8)$

Endocarp

Cell division rapid $(1) \ldots \ldots \ldots \ldots \ldots \ldots \ldots$ Cell division slows . . ceases $(1,8,10)$

Cell division generally longer in

endocarp than mesocarp (8)

Cell division continues longest

at the basal end (8)

\section{Cell expansion}

$70 \%-80 \%$ of mature size by the end of Stage I $(10)$

"Gumming"

Ducts fill with a gummy

polysaccharide material;

continues to maturity $(8,9)$

\begin{tabular}{ll}
$\begin{array}{l}\text { Anatomical distinction } \\
\text { of endocarp and mesocarp }\end{array}$ & $\begin{array}{c}\text { Chemical distinction of } \\
\text { endocarp and mesocarp }\end{array}$ \\
\hline $\begin{array}{c}\text { Endocarp cells are thick } \\
\text { walled with a minimum } \\
\text { of intercellular space. }\end{array}$ & $\begin{array}{l}\text { Clear demarcation is evident } \\
\text { between the cream-colored } \\
\text { endocarp and the green } \\
\text { mesocarp. }(1,6,8)\end{array}$ \\
$\begin{array}{c}\text { Mesocarp cells are thin } \\
\text { walled and larger in }\end{array}$ & .
\end{tabular}

walled and larger in size $(1,6,8,10)$

Cell arrangement

Lignification

Cells parallel to each other at

the suture; cells may separate

and split (8)

Begins at the apical end and proceeds to

basal region $(1,8,10)$

Ventral suture and inner walls harden

most rapidly $(8,10)$

Dorsal and ventral bundles

Bundles are initiated at the base of the carpel and run through its entire length prior to full bloom (8)

Dorsal bundle lies in a shallow groove on the dorsal

cdge of the endocarp (8)

Two ventral bundles lie in decp grooves on the

ventral edge of the endocarp (8)

Bundles exhibit greater branching at the apical end

than the basal half of the fruit $(8)$

Decrease in size during lignification

may cause strain (10)

riaan (1989) used heat unit accumulation to model carbon demand in the developing fruit of early and late maturing cultivars of peach. They speculate that the accumulated growing degree days required before cell expansion occurs is responsible for differences in ripening period.

Although heat units may be an indicator $\underline{\text { Split pit }}$

Cell wall fractionation occurs (4)

Water retention is higher in split pit

than in normal pit development (4) of environmental chronology, there is little agreement in the literature on how to determine heat accumulation in peach. Fischer (1962) used a 10C base temperature for 


\begin{tabular}{cccccc}
\hline \hline & & & Days after full bloom & \\
\hline 0 & 10 & 20 & 30 & 40 & 50 \\
\hline & Initial phase of exponential growth-Stage 1 $(2)$ & & Growth lag (variable with cultivar)-Stage II & 60 \\
\hline
\end{tabular}

Pollination

Reproductive structures

Extends several days (1)

One ovule aborts $(8,10)$

\section{Embryo sac elongation}

Rapid development; extends

length of the nucellus $(6,8)$

Fertilization $(6,8,10)$

Nucellus and integument development

Rapid and continuous growth $(5,6,8)$

Nucellus cells compact, uniform, and isodiametric (6)
Maximum growth of nucellus achicved;
degradation begins and is replaced
by growing endosperm $(3,6)$
Cessation of nucellus and integument growth
are within five days of each other $(6,10)$

Endosperm cytokinesis

Cell walls first appear near the embryo

near the mycopylar end $(6,7,8)$

Cell division continues $4-7$ days $(6,7)$

Rapid embryo development

Cell division proceeds three

dimensionally and rapidly $(7,8)$

"Spherical" Stage continues 10-14 days $(7,8)$

Domed apex flattens; cell

division rate grcatest (7)

"Pit" and funicular bundles

Pit and funicular bundles lic partly or wholly within the

pit; they enter directly from the receptacle.

Pit bundles number $10-12$

Two funicular bundles lead to each ovule, but the two

often fuse to feed the surviving ovule (8)

${ }^{2}$ The numbers in parcntheses refer to the following citations: (1) Addoms, et al., 1930, (2) Canners, 1919, (3) Dorsey and McMunn, 1926, (4) Evert et al., 1988, (5) Harold, 1935, (6) Lilien-Kipnis and Lavee, 1971, (7) Lombard and Mitchell, 1962. (8) Ragland, 1934, (9) Reeve, 1959. (10)Zucconi, 1987.

growth. Munoz et al. (1986) used calculated temperature bases from 2.2 to $4.4 \mathrm{C}$ and DeJong and Goudriaan used 7C. Topp and Sherman (1989) were able to use mean temperatures to predict the ripening period of several low-chill peach cultivars.

In light of cuitivar differences in the perception of heat units, it is not possible at this time to present an environmentally based chronology of developmental events applicable to all cultivars under diverse conditions. However, we do believe that the basic chronology of developmental events described for Maryland would generally exist anywhere peaches are grown.

Environmental indices (growing degree days and heat accumulation units) are valuable indices for the rate of fruit growth, especially in the early stages of development (Batjer and Martin, 1965; DeJong and Goudriaan, 1989; Fischer, 1962; Topp and Sherman, 1989). Unfortunately, temperature interactions with photosynthesis, water potential, respiration, and other physiological processes make development of a universally suitable model difficult. Because of the complexity of the whole tree system and the interaction of the environmental factors, no single environmental index has been developed that explains the variability in fruit growth.

A physiological index is any chemical as- say that indirectly permits the stage of fruit development to be determined. Chalmers and van den Ende (1975) used the change in fresh and dry matter accumulation as physiological indices of growth. They found that the three stages of dry weight accumulation did not correspond to changes in fresh weight or cheek diameter. It was clear that Connors' three-stage classification system was an inappropriate model to explain the factors regulating fruit development.

The rate of oxidative browning and the degree of polyphenyloxidase and peroxidase activity have been evaluated recently as indices of Stage I fruit development (Gage, 1989). While indices provide specific information on fruit makeup, they are not practical as field evaluation tools. Chalmers and van den Ende (1975) and DeJong and Goudriaan (1989) have provided insight on carbohydrate demand and dry weight accumulation in peach fruit but have not related those demands to specific developmental events.

\section{Anatomical changes relative to early peach fruit development}

The value of a developmental index is enhanced when it can be related to specific anatomical or developmental events in the fruit. The important anatomical events in peach fruit tissue systems are identifiable from the existing literature. Data collection by the various researchers varied considerably in frequency and methodology. Date of full bloom was almost always given (or could be estimated), but date of pit hardening had to be estimated from graphs or anatomical descriptions. We attempted to normalize the data collected from different locations to conditions found in Maryland; full bloom was taken as time $\mathrm{O}$ and the length of Connors' Stage I (bloom to onset of pit hardening) was normalized to 45 days.

Using the normalized index, Table 1 was developed to describe the anatomical events that occur during growth. For organizational simplicity, the table includes those developmental events that occur from bloom to endocarp sclerification in the mesocarp and exocarp, the endocarp, and the reproductive tissues.

A 2- to 3-day variability is assumed for each entry within the figure; the day-afterfull-bloom chronological index is used to facilitate comparison of data in the literature. Each anatomical event/observation is listed with its approximate time-based boundaries, with multiple citations where conflict occurred. The final component of each figure is the vascular development of each tissue system. Various assumptions we have made are affected by environmental factors beyond control. Temperature has an especially pro- 
found effect on development period of the peach (Batjer and Martin, 1965; DeJong and Goudriaan, 1989; Fischer, 1962; Topp and Sherman, 1989). Since the literature reviewed on anatomical development did not provide reliable temperature data, the developmental events are present within the subjective, but universally recognized, framework of days after full bloom. Data in Tables 2 and 3 facilitate the use of our chronology outside of Maryland. In Table 2, we present the 31-year monthly averages for minimum, mean, and maximum temperatures during the period of peach ripening (Moyer and Moyer, 1987). In Table 3, we present the 31-year weekly average temperature, and accumulated growing degree hours using a 4, 7, and 10C base during early fruit development (Moyer and Moyer, 1987). An average bloom date of 4 Apr. is assumed, because it is typical for Maryland, and corresponds to the climatological calendar.

\section{Anatomical development in peach fruit}

Anatomical changes in developing peach mesocarp and exocarp tissues are summarized in the first section of Table 1 . The transition from the rapid growth in fruit length to the rapid growth in cheek diameter coincides with the beginning of cell expansion. The cell division/cell expansion interface depends primarily on the location and type of cell; cell division continues longest in the outside cell layers and at the basal portion of the fruit. Although most sources estimate cessation of cell division at 3 weeks after full bloom (Addoms et al., 1930; Ragland, 1934), Zucconi (1987) states that ceil division may continue for up to 5 weeks after full bloom. The cell walls of mesocarp parenchyma cells thicken as the fruit enters Stage II, a period corresponding to the hardening of the endocarp cell walls. A thick layer of trichomes, which are evident early in development, diminish as cell expansion begins. Finally, mesocarp duct formation formed by cell separation in the central region of the vascular bundle (Reeve, 1959) is active throughout the life of the fruit.

Endocarp tissue (middle section, Table 1) division and expansion patterns are similar to those of the mesocarp, with cell division generally continuing longer in the endocarp (Connors, 1919). After full bloom, there is a distinct difference between the cell structure of the two tissues, both anatomically (wall structure and intercellular space) (Addoms et al., 1930; Lilien-Kipnis and Lavee, 1971; Ragland, 1934) and chemically (pigmentation) (Addoms et al., 1930; LilienKipnis and Lavee, 1971; Ragland, 1934). Stress to the parallel cell arrangement about the suture leads to split pit, a condition typical in early session cultivars and in cultivars that retain water in the endocarp (Evert et al., 1988).

Signification of endocarp tissue occurs (Addoms et al., 1930; Ragland, 1934) at the end of Stage I. Signification is best termed a process, beginning at the apical end, continuing to the ventral suture and inner walls, and terminating with a hard pit (Ragland,

Table2. Monthly averages of daily minimum, mean, and maximum temperatures in Maryland during the peach growing season.

\begin{tabular}{lccc}
\hline \hline Month & Minimum $\left({ }^{\circ} \mathrm{C}\right)$ & Average $\left({ }^{\circ} \mathrm{C}\right)$ & Maximum $\left({ }^{\circ} \mathrm{C}\right)$ \\
\hline April & 5.3 & 12.6 & 18.7 \\
May & 10.5 & 17.1 & 23.7 \\
June & 15.2 & 21.6 & 28.0 \\
July & 17.7 & 23.9 & 30.2 \\
August & 16.8 & 23.2 & 29.6 \\
September & 12.7 & 19.5 & 26.3 \\
\hline
\end{tabular}

"Thirty-one-year average from May 1956 to Dec. 1986 at Upper Marlboro, Prince George's County, Md. Weather Station no. 18049070 (Latitude $=38.49^{\circ} \mathrm{N}$, Longitude $=76.46^{\circ} \mathrm{W}$; elevation $=37 \mathrm{~m}$ above sea level).

Table 3. Weekly growing degree day (GDD) accumulation in Maryland during peach growing season at 4,7 , and $10 \mathrm{C}$ base temperatures.

\begin{tabular}{|c|c|c|c|c|c|c|c|}
\hline \multirow{2}{*}{$\begin{array}{l}\text { Weeks } \\
\text { after } \\
\text { bloom }^{y}\end{array}$} & \multirow{2}{*}{$\begin{array}{l}\text { Mean } \\
\text { temp } \\
\left({ }^{\circ} \mathrm{C}\right)\end{array}$} & \multicolumn{2}{|c|}{$4 \mathrm{C}$} & \multicolumn{2}{|c|}{$7 \mathrm{C}$} & \multicolumn{2}{|c|}{$10 \mathrm{C}$} \\
\hline & & $\begin{array}{c}\text { Weekly } \\
\text { GDD }\end{array}$ & $\begin{array}{c}\text { Cumul. } \\
\text { GDD }\end{array}$ & $\begin{array}{c}\text { Weekly } \\
\text { GDD }\end{array}$ & $\begin{array}{c}\text { Cumul. } \\
\text { GDD }\end{array}$ & $\begin{array}{c}\text { Weekly } \\
\text { GDD }\end{array}$ & $\begin{array}{l}\text { Cumul } \\
\text { GDD }\end{array}$ \\
\hline 1 & 9 & 35 & 35 & 14 & 14 & 0 & 0 \\
\hline 2 & 12 & 56 & 91 & 35 & 49 & 14 & 14 \\
\hline 3 & 14 & 70 & 161 & 49 & 98 & 28 & 42 \\
\hline 4 & 14 & 70 & 231 & 49 & 147 & 28 & 70 \\
\hline 5 & 15 & 77 & 308 & 56 & 203 & 35 & 105 \\
\hline 6 & 17 & 91 & 399 & 70 & 273 & 49 & 154 \\
\hline 7 & 18 & 98 & 497 & 77 & 350 & 56 & 210 \\
\hline 8 & 18 & 98 & 595 & 77 & 427 & 56 & 266 \\
\hline 9 & 20 & 112 & 707 & 91 & 518 & 70 & 336 \\
\hline 10 & 22 & 126 & 833 & 105 & 623 & 84 & 420 \\
\hline 11 & 22 & 126 & 959 & 105 & 728 & 84 & 504 \\
\hline 12 & 22 & 126 & 1085 & 105 & 833 & 84 & 588 \\
\hline 13 & 23 & 133 & 1218 & 112 & 945 & 91 & 679 \\
\hline 14 & 23 & 133 & 1351 & 112 & 1057 & 91 & 770 \\
\hline 15 & 24 & 140 & 1491 & 119 & 1176 & 98 & 868 \\
\hline 16 & 24 & 140 & 1631 & 119 & 1295 & 98 & 966 \\
\hline
\end{tabular}

${ }^{2}$ Thirty-one-year average from May 1956 to Dec. 1986 at Upper Marlboro, Prince George's County, Md. Weather Station no. 18049070 (Latitude $=38.49^{\circ} \mathrm{N}$, Longitude $=76.46^{\circ} \mathrm{W}$; elevation $=37 \mathrm{~m}$ above sea level).

${ }^{y}$ Assumes an average bloom date of 4 Apr.

1934; Zucconi, 1987). It is noteworthy that the main three bundles that supply the endocarp lie not within the tissue, but in deep grooves on each side (Ragland, 1934).

The reproductive tissue changes are shown in the bottom section of Table 1 . The wide range in time of fertilization represents the varied length noted in the literature (LilienKipnis and Lavee, 1971; Ragland, 1934; Zucconi, 1987). Nucellus and integument growth proceed parallel, and these tissues enclose the liquid endosperm before cytokinesis (Lilien-Kipnis and Lavee, 1971). Cytokinesis begins at the apical end of the endosperm (Lilien-Kipnis and Lavee, 1971; Ragland, 1934). This pattern is similar to the initiation of endocarp Signification. The peach embryo is extremely small before Stage II, but the 3- to 4-week developmental period following incipient endosperm cytokinesis is rapid and can be divided into distinct stages (Lombard and Mitchell, 1962). The surviving ovule is fed through the funicular bundles, which enter through the receptacle, and seemingly do not branch into the endocarp or mesocarp tissues (Ragland, 1934).

\section{Rationale for a development scheme for peach fruit}

We have attempted to construct a developmental framework for early fruit development that can be correlated with developmental growth indices. Although it is somewhat subjective, we have used a chronological index (days after full bloom) to facilitate use and compared data from the existing literature on anatomical development in the mesocarp and exocarp, the endocarp, and reproductive tissues with respect to cell division, cell expansion, pigmentation, and tissue differentiation. We recognize that environmental, cultural, and genetic factors introduce variability into development events, affecting the time of their occurrence. We have assumed that the sequence of anatomical development is relatively unchanged. We have made attempts to normalize this variability to our growing conditions in Maryland where possible. Normalization of the data to local conditions allows us to compare treatment effects from diverse cultivars, sites, and management conditions.

Efforts to develop morphological, physiological, and environmental indices of growth have been used to reduce the variability inherent within the chronological indices, but have not been correlated directly to developmental processes within the fruit itself. In essence, researchers have been predicting developmental events using indirect indices of growth, but have generally failed to verify those results with anatomical investigations,

A critical need exists for growth indices to be interpreted within a tissue-specific developmental framework. This framework 
(Table 1) will allow comparison of diverse treatment effects on a direct developmental basis. This goal will be aided if the fruit research community offers suggestions that will increase the utility of the framework for understanding fruit growth and development.

\section{Literature Cited}

Addoms, R. H., G.T. Nightingale, and M.A. Blake 1930. Development and ripening of peaches as correlated with physical characteristics, chemical composition, and histological structure of the fruit flesh: II. histology and microchemistry. N.J. Agr. Expt. Sta. Bul. 507:3-19.

Baker, G.A. and R.M. Brooks. 1944. Climate in relation to deciduous fruit production in California: III. Effect of temperature on number of days from full bloom to harvest of apricot and prune fruits. Proc. Amer. Soc. Hort. Sci. 45:95103.

Batjer, L.P. and G.C. Martin. 1965. The influence of night temperature on growth and development of early Redhaven peaches. Proc. Amer. Soc. Hort. Sci. 87: 139-144.

Brown, D.S. 1952. Climate in relation to deciduous fruit production in California: V. The usc of temperature records to predict the time of harvest of apricots. Proc. Amer. Soc. Hort. Sci. 60:197-203.

Chalmers, D.J. and B. van den Ende. 1975. A reappraisal of the growth and development of the peach fruit. Austral. J. Plant Physiol. 2:623634.
Connors, C.H. 1919. Growth of fruits of peach. N.J. Agr. Expt. Sta. Annu. Rpt. 40:82-88.

Crane, J.C. 1963. Parthenocarpic peach development as influenced by the time of gibberellin application. Proc. Amer. Soc. Hort. Sci. 83:240247.

DeJong, T.M. and J. Goudriaan. 1989. Modeling peach growth and carbohydrate requirements: reevaluation of the double-sigmoid growth pattern. J. Amer. Soc. Hort. Sci. 114:800-804.

Dorsey, M.J. and R.L. McMunn. 1926. The development of the peach seed in relation to thinning. Proc. Amer. Soc. Hort. Sci. 23:402-413.

Evert, D. L., T.P. Gaines, and B.G. Mullinix. 1988. Effects of split-pit on elemental concentrations of peach fruit during pit hardening. Scientia Hort. 34:55-65.

Fischer, D.V. 1962. Heat units and number of days required to mature some pome and stone fruits in various areas of North America. Proc. Amer. Soc. Hort. Sci. 80:114-124.

Gage, J.D. 1989. Tissue specific developmental changes in polyphenol oxidase, peroxidase, and net browning in Prunus persica (L. ) Batsch. Master's Thesis, Univ. of Maryland, College Park.

Harrold, T.J. 1935. Comparative study of the developing and aborting fruits of Prunus persica. Bet. Gaz. 96:505-520.

Lilien-Kipnis, H. and S. Lavee. 1971. Anatomical changes during the development of 'Ventura' peach fruits. J. Hort. Sci. 46:103-110.

Lombard, P.B. and A.E. Mitchell. 1962. Anatomical and hormonal development in 'Redhaven' peach seeds as related to the timing of
NAA for fruit thinning. Proc. Amer. Soc. Hort. Sci. 80:163-171.

Moyer, W.J. and R.C. Moyer, 1987. Climate of Upper Marlboro, Maryland, Md. Agr. Expt. Sta. Bul. no. 13.

Munoz, C., G. Sepulveda, J. Garcia-Huidobro, and W.B. Sherman. 1986. Determining thermal time and base temperature required for fruit development in low-chilling peaches. HortScience 21:520-522.

Ragland, C.H. 1934. The development of the peach fruit, with special reference to split-pit and gumming. Proc. Amer. Soc. Hort. Sci. 31:121.

Reeve, R.M. 1959. Histological and histochemical changes in developing and ripening peaches. Amer. J. Bot. 46:241-248.

Stutte, G.W. and J. Gage. 1990. Gibberellin inhibits fruit abscission following seed abortion in peach. J. Amer. Soc. Hort. Sci. 115:107110.

Topp, B.L. and W.B. Sherman. 1989. The relationship between temperature and bloom to ripening period in low-chill peach. Fruit Var. J. 43:155-159.

Tukey, H.B. 1936. Development of cherry and peach fruits as affected by destruction of the embryo. Bot. Gaz. 98:1-24.

Weinberger, J.H. 1948. Influence of temperature following bloom on fruit development period of Elberta peach. Proc. Amer. Soc. Hort. Sci. 51:175-178.

Zucconi, F. 1987. Peach, p. 303-332. In: S.P. Monseliese (cd.). Handbook of fruit set and development. CRC Press, Boca Raton, Fla. 